\title{
Bioindication on the basis of benthic diatoms: Advantages and disadvantages of the Polish phytobenthos lake assessment method (IOJ - the Diatom Index for Lakes)
}

\author{
Bioindykacja na podstawie okrzemek bentosowych: \\ Mocne i słabe strony polskiej metody oceny jezior \\ na podstawie fitobentosu (IOJ - Indeks Okrzemkowy Jezior)
}

\begin{abstract}
*Mgr Aleksandra Bielczyńska - Department of Freshwater Assessment Methods and Monitoring, Institute of Environmental Protection - National Research Institute, Kolektorska 4 Str., 01-692 Warsaw, tel.: (48 22) 37-50-619, e-mail: a.bielczynska@ios.edu.pl
\end{abstract}

Keywords: biological monitoring, phytobenthos, diatom indices, Water Framework Directive

Słowa kluczowe: monitoring biologiczny, fitobentos, wskaźniki okrzemkowe, Ramowa Dyrektywa Wodna

\section{Abstract}

Diatoms are widely used for bioindication because of their sensitivity to anthropogenic pressures (e.g. eutrophication or acidity of waters). In many countries in the world, work has been undertaken to develop and implement diatom indices. Since 2000, in the Member States of the European Union, this has been done as part of the implementation of the Water Framework Directive. The results of lake assessment obtained using the Polish method based on epiphytic diatoms (IOJ - Indeks Okrzemkowy Jezior $=$ the Diatom Index for Lakes) are greatly different from those provided by the other ecological status assessment methods. The purpose of this article is to review the scientific literature on the use of phytobenthos for bioindication in order to identify the advantages and disadvantages of the Polish IOJ method and to indicate the possible directions of improvements in this method. The literature evidencing the variability of phytobenthos related to its habitat, the spatial variability at the scale of a lake and the variability in the growing season was reviewed. The cited writings indicate that the further specification of guidelines for the sampling procedure and an increase in the number of survey sites could enhance the functionality of the Polish lake assessment method. It has also been suggested that it may be useful to test the effect of the seasonal variability of a phytobenthos assemblage on its bioindicator value.

๑) IOŚ-PIB

\section{INTRODUCTION}

In past century, there was a substantial change in the approach to the issue of water quality assessment [Soszka 2002]. In the 1970s, in Europe, most attention was paid to the analyses of waters focused on their usefulness for drinking, recreation or economic use. For this purpose, selected physicochemical parameters and microbiological purity were investigated. In the 1980 s, a more holistic approach to water assessment, called ecosystem-based, began to prevail. It consisted in an assessment of not only waters

\section{Streszczenie}

Wrażliwość okrzemek na presje antropogeniczne (np. eutrofizację lub zakwaszenie wód) skutkuje ich szerokim zastosowaniem w bioindykacji. W wielu krajach naświecie podjęto się opracowania lub stosowania opracowanych już indeksów biotycznych opartych na okrzemkach fitobentosowych, służących ocenie stanu wód. Od 2000 roku w krajach członkowskich Unii Europejskiej odbywa się to w ramach wdrażania Ramowej Dyrektywy Wodnej. Wyniki uzyskane przy użyciu polskiej metody oceny jezior na podstawie okrzemek epifitycznych (IOJ - Indeks Okrzemkowy Jezior), znacznie odbiegają od wyników jakie dają pozostałe metody oceny stanu ekologicznego. W niniejszym artykule podjęto się prześledzenia literatury naukowej dotyczącej fitobentosu w bioindykacji w celu zidentyfikowania silnych i słabych stron polskiej metody IOJ oraz wskazania potencjalnych kierunków udoskonalenia metody. Prześledzono literaturę dokumentującą zmienność fitobentosu związaną z jego siedliskiem, zmienność przestrzenną w skali jeziora oraz zmienność w sezonie wegetacyjnym. Przytoczone piśmiennictwo wskazuje na to, że doprecyzowanie wytycznych do procedury poboru prób oraz zwiększenie liczby stanowisk badawczych mogłoby zwiększyć funkcjonalność polskiej metody oceny jezior. Zasugerowano również, że warto podjąć się przetestowania wpływu zmienności sezonowej zespołu fitobentosu na jego wartość bioindykacyjną.

but also the whole reservoir in terms of its characteristics that affect the organisms that colonise it. At that time, in Poland, the SOJJ (System Oceny Jakości Jezior = Lake Quality Assessment System) was developed [Kudelska et al. 1997], under which the development of the catchment, its size and selected morphological and hydrographic parameters of the lake were analysed, in order to assess the susceptibility of the lake to degradation. Another milestone in the water assessment was the implementation of 
Directive 2000/60/EC (the Water Framework Directive) [Directive 2000]. The main emphasis was then placed on the research to determine the response of organisms to anthropogenic pressures rather than the analysis of the pressures themselves. According to the Directive, status of surface waters is assessed on the basis of the condition of five groups of organisms: phytoplankton, macrozoobenthos, ichthyofauna, macrophytes and phytobenthos. Diatoms are an element of aquatic flora that has been used for bioindication for many years. The identification of their different environmental preferences made it possible to develop water quality assessment methods based on phytobenthic diatoms. They provided the basis for developing a number of indices assessing the degree of saprobisation, eutrophication, salinity or acidity of surface waters [Kawecka, Eloranta 1994].

Just as macrophytes, the littoral phytobenthos is affected by nutrients brought into waters in the littoral zone; therefore, it responds to the pressures at a local scale. In contrast to phytoplankton living in the pelagial, it does not reflect the status of the whole lake. Compared with macrophytes, phytobenthos quickly responds to pollutants, because of its short generation time [Schneider et al. 2012]. For the above-mentioned reasons, the littoral phytobenthos is an early warning indicator for a pressure emerging in the catchment. It can demonstrate the presence of the eutrophication pressure related, for example, to the use of coastal areas for recreation purposes, even before its effects become visible in the pelagial as enhanced nutrient contents or enhanced phytoplankton biomass [Lambert et al. 2008, Rosenberger et al. 2008, Thomas et al. 2011]. For these reasons, it is recommended that this element should not be used for bioindication as an independent assessment method but rather to complement the methods based on phytoplankton and macrophytes [Picińska-Fałtynowicz 2011].

The Water Framework Directive (WFD) [Directive 2000] came into effect in 2000, establishing guidelines for surface water management. One of the requirements which the European law has set is the need to monitor ecological quality in rivers and lakes on the basis of biological quality elements. These elements include 'macrophytes and phytobenthos'. The WFD recommends the investigation of the composition and abundance of these elements. In order to implement the Directive, the European countries have had to develop new phytobenthosbased assessment methods adapted for the purposes of assessing the ecological status rather than - as before - the trophic state, the saprobity or the acidity level. In many cases, this was done by adaptation of the already existing methods, through the determination of the reference conditions and their treatment as reference points. In Poland, two components of the biological quality element 'macrophytes and phytobenthos' were treated separately and an assessment method was developed for each of them. Diatoms were selected as representative of the whole phytobenthos, whilst the other groups of organisms making up phytobenthos were not investigated. To date, in eleven European countries, phytobenthos-based indices have been developed in accordance with the guidelines of the WFD. These include Belgium, Germany, Finland, France, Hungary, Ireland, Italy, Poland, Sweden, Slovenia and the United Kingdom. These countries took part in the intercalibration exercise, which demonstrated that diatoms in different European countries responded in a similar way to changes in the trophic state and that the indices that had originally been developed for river assessments proved useful for lake monitoring [Kelly et al. 2014, Poikane 2014]. By 2013, nine countries of the European Union had implemented phytobenthos-based water quality assessment methods [DeNicola, Kelly 2014]

The multimetric Diatom Index for Lakes (IOJ) based on phytobenthic diatoms is used for lake assessments in Poland [Picińska-Fałtynowicz, Błachuta 2010, Poikane 2014]. The purpose of this method is to assess the trophic state of a reservoir and to assess the deviation of a phytobenthos assemblage from the reference state. In accordance with the method, in order to assess the whole lake, material should be collected from at least one survey site. The effect of this recommendation is that in practice, one sample is collected from one survey site. A research site should be located in the littoral, in a place which is not exposed to wave action. After reducing its volume, a phytobenthos sample is digested using a strong oxidant. A clean subsample is mounted on a permanent slide. Subsequently, about 400 valves of the indicator and reference taxa present in the sample are determined and counted. The index is calculated on the basis of the shares of the particular taxa in the sample, taking into account their indicators of sensitivity to the trophic state and the weight value, drawn from the German method [Schaumburg et al. 2007]. On the basis of the IOJ, a lake can be assigned to one of the five classes of ecological status, in accordance with the WFD.

The Polish phytobenthos lake assessment method was developed in 2006. Two years later, it started to be used in the State Environmental Monitoring System. On the basis of data collected by the Provincial Inspectorates for Environmental Protection in 2008-2009, the method was revised [PicińskaFaltynowicz 2011]. That version of the method was subjected to the international intercalibration exercise. The result of that exercise demonstrated that the boundaries between moderate and good ecological status as well as between good and high ecological status had been underestimated with respect to other countries. In consequence of this, necessary corrections were introduced into this method [Kelly et al. 2014, Poikane 2014].

For many years, the Institute of Environmental Protection National Research Institute in Warsaw has exercised substantive supervision over the monitoring of lakes in Poland. On the basis of long-term data collected by the Provincial Inspectorates for Environmental Protection, it was found that the lake assessments based on IOJ were substantially different from those based on other biological elements (macrophytes - ESMI, phytoplankton - PMPL) (Fig. 1). In the case of the lake classification in 20102013, phytobenthos indicated relatively high ecological status of lakes in Poland. According to IOJ, almost $80 \%$ of the lakes surveyed achieved at least good ecological status, whereas their number according to other indices was 57,8\% - ESMI [Ciecierska, Kolada 2014] or 51,6\% - PMPL [Hutorowicz, Pasztaleniec 2014]. In addition, in no case did IOJ indicate bad ecological status, whilst poor status was found in the case of one lake only, whereas the other indices showed a more uniform distribution and presented a full spectrum of ecological status. 
Phytoplankton PMPL

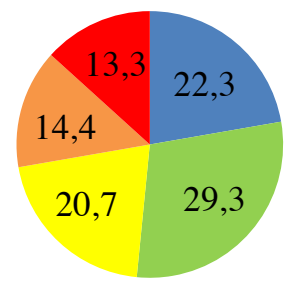

Macrophytes ESMI

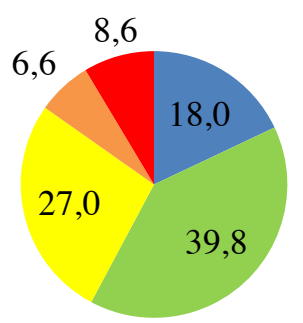

Phytobenthos IOJ

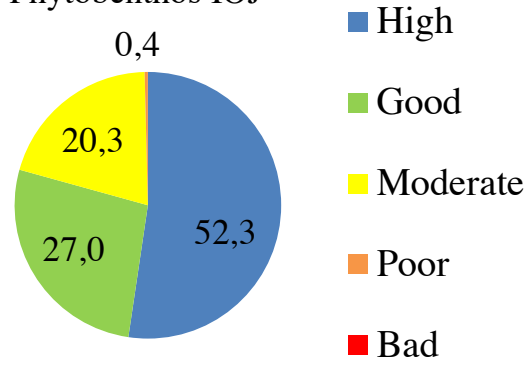

Fig. 1. Percentage of lakes assigned to the particular classes of ecological status on the basis of different indices, data from 2010 to 2013 for 256 lakes in which all the three biological elements were surveyed. Source: State Environmental Monitoring System

Quite frequently, IOJ indicates a significantly different environmental status than PMPL or ESMI do, for example, high status when other elements suggest bad status. A high score based on phytobenthos seems doubtful, given the fact that IOJ is an index designed to illustrate the impact of eutrophication and the most Polish lakes are susceptible to this pressure [Hillbricht-llkowska 1997]. In accordance with the 'one-out, all-out' principle laid down in the WFD, the final assessment is based on the element that indicates the worst ecological status. Phytobenthos is an element that extremely rarely affects the final assessment. Therefore, substantial expenditures on its surveys becomes questionable, because its role in bioindication is a slight one.

The observed differences provided the ground for the decision taken at the Institute of Environmental Protection - National Research Institute to take a closer look at the above-mentioned lake assessment method, to identify its advantages and disadvantages and to determine its possible improvements. For this purpose, the scientific literature on phytobenthos-based bioindication was analysed. The aim of this study is to present the Polish lake assessment method on the basis of phytobenthos against the background of knowledge drawn from the scientific literature. The recommendations and guidelines laid down in scientific works and strategic documents of the European Union were analysed from this point of view. The monitoring practice in Poland and other European countries was also compared. As a result of this comparison, measures that can contribute to improving IOJ are presented.

\section{RESULTS AND DISCUSSION}

\subsection{The subject matter of the studies}

The Polish method for water quality assessment based on phytobenthos is limited to the examination of phytobenthic diatoms. Such an approach to phytobenthos monitoring is often applied in European countries [Birk et al. 2010]. As demonstrated by DeNicola and Kelly [2014], the inclusion of the other groups of phytobenthos in the assessment does not significantly change its result. Diatoms are highly sensitive to water fertilisation; therefore, they are good indicators of the trophic state of waters [King et al. 2000]. Owing to the specific structure of diatoms (the presence of a silica frustule), they do not decompose readily. This ensures easy access to paleolimnological data (diatom frustules deposited in bottom sediments), enabling the determination of the reference conditions. In addition, after the organic part of the cell has been digested, a permanent slide can be made. The slide can be stored without the risk of damage practically without any limitations.

Many studies have demonstrated that the relationships between the diatom biomass and the trophic state are not linear. In the conditions of a high trophic state, the biomass of phytobenthic diatoms is reduced by the grazing pressure and the competition with phytoplankton. For this reason, the biomass of benthic diatoms is not a good measure for eutrophication. Their taxonomic composition is a much better indicator [King et al. 2006, Lambert et al. 2008, Thomas et al. 2011, DeNicola, Kelly 2014]. The indicators based on the species diversity of diatoms do not always reflect the trophic state of a reservoir, either [Danilov, Ekelund 2000], and they are difficult to interpret [Kawecka, Eloranta 1994, DeNicola, Kelly 2014]. Kelly [2013] proposed that the characteristics of diatoms (e.g. their classification to functional groups) should be included in the assessment, just as in the case of bioindication based on macrozoobenthos. For now, this is impossible, given the fact that the ecology of phytobenthic diatoms in lakes has not been sufficiently explored [Cantonati, Lowe 2014]. Therefore, the use of the relative abundance of indicator diatom taxa, as applied in the Polish methodology, to determine the value of the index is justified and supported by scientific writings.

\subsection{Substrates}

In the littoral of lakes, benthic diatoms colonise a number of different substrates. In view of its structure, stability, location and chemistry, each of the substrates creates different environmental conditions and, in consequence, it is colonised by a different phytobenthic assemblage [Kawecka, Eloranta 1994]. Diatom groups that colonise stones (epilithon), the surface of macrophytes (epiphyton) and artificial substrates are most often used for the purposes of environmental monitoring and assessment. Owing to its nature, epipelon (the assemblage that colonises bottom sediments) is affected by interstitial waters rather than by lake waters only; therefore, its bioindicator value is low [King et al. 2006]. This was confirmed by Lambert et al. [2008], who demonstrated that epilithon responds more strongly to changes in the trophic state than epipelon does. Moreover, the diatom 
assemblage in bottom sediments contains sedimented frustules of planktonic diatoms; therefore, it cannot be representative of benthic organisms [Poulíčková et al. 2004].

The Polish method recommends that phytobenthos samples should be collected from macrophytes (epiphyton), and possibly from stones (epilithon), if there are no macrophytes in the lake. In the monitoring practice of European countries, diatom samples are commonly collected from either the epiphyton or the epilithon [Birk et al. 2010, Kelly et al. 2014]. Many scientific publications have indicated that both the epiphyton and the epilithon are a suitable material for bioindication in lakes. Each of these studies covers research on a small number of lakes; therefore, for now, there is no clear ground for determining which of these communities is the better and more universal water quality indicator. However, it is important that the phytobenthic assemblages on macrophytes and stones are different from each other and, therefore, the indices calculated on the basis of these groups cannot be compared with each other [King et al. 2006].

As Kitner and Poulíčková [2003] demonstrated, in the epilithon, there are many species of planktonic diatoms. They attributed it to the relatively large probability of the 'contamination' of the epilithon by the epipelon in stagnant waters. Zębek et al. [2012] compared the epiphyton and epilithon assemblages and the diatoms from an artificial substratum in a heavily modified, eutrophic lake and determined that each of these assemblages was dominated by a different taxon. Kitner and Poulíčková [2003] and Bennion et al. [2014] demonstrated that the differences between substrates did not always cause significant differences between the values of bioindicators based on phytobenthos. However, in alpine lakes, the differences between the indicators calculated for different substrates proved to be substantial [Pouličková et al. 2004]. The epilithon showed a higher trophic state than the epiphyton did, which was considered an overestimation after the physicochemical characteristics of waters were compared. The epipelon demonstrated an even more overestimated trophic state. Consequently, these researchers recommended the use of the epiphyton for bioindication.

The epiphyton assemblage itself is not uniform, and it is affected by factors other than the trophic state of a reservoir. One of these factors is the shape of a plant that gives rise to the formation of microhabitats and sometimes limits access to light. Another factor that affects the epiphyton is the intravital release of chemical substances by macrophytes, which causes a change in the contents of nutrients or dissolved organic matter in the vicinity of plants. Plants can also release compounds of allelopathic nature. The chemistry and shading by plants are the factors that cause the differences observed amongst the species compositions of the epiphyton from different macrophyte species. The research carried out by Cattaneo et al. [1998] indicates that submerged macrophytes with a well-developed surface are colonised by diatoms with greater biomass and lower species diversity than those of macrophytes with floating leaves. The impact of macrophytes on the epiphyton seems to vary depending on the trophic gradient: in oligotrophic lakes, the intravital release of nutrients by plants is more important, whereas in reservoirs with a higher trophic state, this additional source of nutrients is not so significant, as shading is the more important factor limiting the growth of the epiphyton [Eminson, Moss 1980, Laugaste, Reunanen 2005]. For the above-mentioned reasons, many researchers have recommended that samples should be collected from one plant species. Blanco et al. [2004] recommended the use of helophytes which commonly occur in Spain, such as Scirpus lacustris L. and Typha latifolia L. In turn, Stenger-Kovács et al. [2007] suggested that samples should be taken from young stems of the common reed (Phragmites australis (Cav.) Trin. ex Steudel). $P$. australis is a cosmopolitan species characterised by broad ecological tolerance. It occurs commonly and abundantly in the moderate climate [Brix 1999, Clevering, Lissner 1999]. $P$. australis also commonly occurs in Poland, irrespective of the geographical region and the trophic state of reservoirs [Pelechaty 2004]. The epiphyton originating from the reed has been investigated, and an ample scientific literature has been dedicated to it [e.g. Müller 1999, Laugaste, Reunanen 2005, Karosienè, Kasperovičienè 2008]. It seems to be a suitable hostplant species to take phytobenthos samples from.

The host-plant species is not the only factor that differentiates epiphyton. Differences have also been observed in the vertical distribution of phytobenthic diatoms on reed stems, caused by the light and chemical gradients and the differentiated impact of wave disturbance at different depths. According to the research by Hoagland and Peterson [1990] and Müller [1999], diatoms exhibit a clear preference for the wave action pressure or the absence of this pressure. In the upper part of a stem, where wave action is more intensive, settled diatom species are more abundant. At greater depth, on the lower parts of stems mobile species, which are less resilient to wave action, are more abundant. Close to the bottom, they have access to nutrient-rich water, but their growth is limited by their access to light [Müller 1999]. Therefore, in assessing water quality, it is important to unify the samples collected in terms of depth too.

The Polish method of lake assessment (IOJ) recommends that epiphyton samples should be collected from places unexposed to excessive wave action, from depths of at least $30 \mathrm{~cm}$, preferably from macrophytes, if they occur in the reservoir surveyed. The section at $0-30 \mathrm{~cm}$ depth is omitted to avoid the collection of diatoms that are affected by strong wave action that can wash them away, intensive radiation that can inhibit their growth [King et al. 2006] and exposure to a periodic contact with the air [Blanco et al. 2004]. The variability of phytobenthos depending on the substrate is well-documented in the literature. In the light of this, it seems well-advised to specify further the instructions for water sampling in the Polish bioindication method. Following the recommendations of King et al. [2006], as far as possible, the diatoms growing on one plant species, for example, the common reed ( $P$. australis), should be collected. Consideration should be given to narrowing the depth range from which samples are collected.

\subsection{The spatial variability at the scale of a lake}

Many abiotic factors (including anthropogenic pressures) cause phytobenthos to vary at the scale of a whole lake. The impact of these factors can be non-uniform along the coastline. The large sensitivity on local nutrient inflows (such as point pollution sources, 
the eutrophication pressure related to hydromorphological modifications or a water inflow from a polluted watercourse) causes littoral diatoms to vary locally. In such a situation, changes first occur in the phytobenthos located close to the point of the nutrient inflow, whereas phytoplankton changes only when the pelagial waters become fertilised [Lambert et al. 2008, Rosenberger et al. 2008, Thomas et al. 2011].

Considering phytobenthos spatial variability, it is essential to set the correct number of sampling sites in order to obtain representative sample. According to the Polish method, samples are taken once a year, mostly from one site in the littoral. This is consistent with the recommendations made by King et al. [2006], who believed that one survey site distant from the pollution sources or the point of water inflow from a river is sufficient for an assessment of a lake, under the assumption that these pollutants are not the subject matter of the studies. However, the State Environmental Monitoring System, operated in accordance with the WFD guidelines, should clearly focus on detecting changes in aquatic environments caused by anthropogenic pressures [Directive 2000].

A large number of studies on the periphyton on different substrates have shown its spatial variability at the scale of a whole water reservoir. Karosienè and Paskauskas [2012] investigated the epiphyton in the Curonian Lagoon. They found differences in the species composition, biomass and abundance of diatoms and cyanobacteria between its northern and southern parts. These differences were attributed to the local water fertilisation in the south caused by an inflow of river water. Similar differences in the species composition of the epiphyton from the common reed were observed in the mesotrophic, flow-through Lake Gulbinas in Lithuania [Karosienè, Kasperovičienè 2008]. There were differences in the biomass, abundance and species diversity of the epiphyton between the sites, one of which was located close to the flow through. In the deep, oligomesotrophic Lake Garda in northern Italy, Spitale et al. [2011] observed changes in the epilithon assemblage depending on the latitude gradient (this lake extends over $50 \mathrm{~km}$ from the north to the south). The changing parameters included the species diversity and the share of protected and sensitive species. The consequences of these changes also included the values of diatom indices at different sites on the lake. The factors that caused the above-mentioned diversity included the nutrient concentration gradient caused by an inflow of fertile waters from the north and the thermal gradient. Zębek et al. [2012] also observed differences in the littoral diatom assemblage in a shallow, eutrophic urban lake (Lake Jeziorak Mały). These differences occurred in the scope of the presence and abundance of tolerant and sensitive taxa and were related to the eutrophication pressure, saprobisation and the substrate type. In the eutrophic Lake Elk in Canada, Brown and Austin [1973] compared the temporal and spatial variability of the phytobenthos growing on an artificial substrate. They found statistically significant differences amongst four research sites. Phytobenthos assemblages were different in terms of the share of dominant taxa. The authors attributed these changes to competing interspecies interactions. Similarly, differences in the share of dominant taxa within a lake could be seen in lakes from the Wel river catchment area in northern Poland [Picińska-Fałtynowicz 2011].
The above examples show that the variability of the phytobenthos assemblage can be found within lakes with a different trophic state, size and geographical location. Moreover, it is not always caused by local pressures related to water fertilisation. The variability of the phytobenthos is also affected, for example, by the temperature and water movement, grazing and other interspecies interactions [King et al. 2006]. Considering phytobenthos spatial variability, it seems necessary to sample phytobentos from several sites along the lake littoral. This practice was used in the course of the intercalibration exercise, when in most participating countries phytobenthos samples were collected from several sites on one lake [Kelly et al. 2014]. Moreover, in the course of the intercalibration, when the reference conditions were determined, samples taken from lakes failing to meet the conditions of the reference lakes (e.g. in the scope of hydromorphological changes or agriculture in the catchment) were allowed, on the condition that a sample was taken far from the pressure source. This procedure was based on the conviction about a local character of the effect of the pressure on phytobenthos. DeNicola and Kelly [2014] recommended that phytobenthos should be taken for monitoring surveys from several sites (they did not specify how many). The European authors who prepared the Guidance for Monitoring under the Water Framework Directive [European Commission 2003] described the spatial variability of phytobenthos as a large one and for this reason suggested that 3-10 transects should be designated for surveys. The practice in Belgium involves the sampling of phytobenthos from nine points all along the lake coast [Vlaamse Milieumaatschappij 2009]. The German method for phytobenthos-based lake assessment recommends the same number of transects as for macrophyte surveys, that is, between 4 and 50 , depending on the size of the lake [Schaumburg et al. 2007]. Consideration should be given to increasing the number of survey sites in the monitoring practice in Poland in order to obtain a more representative sample.

\subsection{The temporal variability}

The already mentioned short generation time of diatoms [Schneider et al. 2012], which causes their quick response to abiotic changes in the environment, also favours their seasonal variability. Castenholz [1960] described the recurrent scheme of seasonal succession where different factors (nutrients or light) limit their growth at the different moments of the season. Phytobenthos undergoes a similar seasonal cycle as phytoplankton does: with peaks of diatom biomass in the spring and late summer and domination of cyanobacteria in the summer. The diatom taxa typical of the spring season (Cymbella, Diatoma, Fragilaria, Gomphonema, Nitzschia, Synedra), the summer season (Epithemia, Rhopalodia) and the autumn season (Epithemia, Rhopalodia, Synedra, Cymbella) can also be distinguished; these groups partly overlap.

In accordance with the Polish method of lake assessment (IOJ), phytobenthos should be sampled once a year, in the period from August to the middle of October, during the second diatom biomass peak in the season. A closer look should be taken at how the phytobenthos diatom assemblage changes in this period and whether these changes do not hamper bioindication. According 
to the Guidance for Monitoring under the Water Framework Directive [European Commission 2003], the seasonal variability of phytobenthos is medium-high; therefore, it is recommended that samples should be taken several times in the growing season. In the mesotrophic Lake Gulbinas in Lithuania, Karosienè and Kasperovičienè [2008] found large changes in the phytobenthos biomass from 7 August, 2002 to 16 October, 2002. However, there were no significant changes in the species composition of diatoms, as the shares of the particular species varied only slightly. Brown and Austin [1973] observed a similar effect. In the eutrophic Lake Elk in Canada, from September to October, the species composition of periphytic diatoms varied slightly. Changes in the domination structure were found. Similar results were published by Shortreed et al. [1983] for several dozen of oligotrophic lakes in British Columbia. None of the abovementioned studies attempted to assess the impact of the observed changes on phytobenthos-based bioindication.

Ács et al. [2005] investigated the shallow humic Lake Velence in Hungary. They demonstrated that the seasonal variability of phytobenthos in that reservoir affected the assessment of its ecological status. The samples taken at one of the five sites in different periods (in August and October) indicated different ecological status. More importantly, the divergent results were related to the difference between moderate and good ecological status, which is most important from the point of view of water management. On the basis of these and other surveys, the authors concluded that the collection of one sample in a year was not sufficient to obtain representative results. In their review study, laying down guidance for phytobenthos research, King et al. [2006] stated that the seasonal variability of diatoms was greater than their spatial variability. They also noted that the temporal variability involved not only their seasonal succession but also - to a lesser extent - their microsuccession related to the age of the biofilm. Other organisms are the first to colonise the surface, whilst others settle on a mature biofilm. The authors assessed that the above-mentioned changes in time should not significantly affect the values of weighted-average-type metrics. However, they recommended that samples collected at the same moment of the season only should be compared with one another. The phytobenthos-based index LTDI (Lake Trophic Diatom Index)

\section{REFERENCES AND LEGAL ACTS}

ÁCS É., RESKÓNÉ N.M., SZABÓ K., TABA G., KISS K.T. 2005. Application of epiphytic diatoms in water quality monitoring of lake Velence - recommendations and assignments. Acta Botanica Hungarica 47: 211-223.

BENNION H., KELLY M.G., JUGGINS S., YALLOP M.L., BURGESS A., JAMIESON J., KROKOWSKI J. 2014. Assessment of ecological status in UK lakes using benthic diatoms. Freshwater Science 33: 639-654.

BIRK S., STRACKBEIN J., HERING D. 2010. WISER methods database. Version: March 2011. Available at: www.wiser.eu/ results/method-database [April 2015].

BLANCO S., ECTOR L., BÉCARES E. 2004. Epiphytic Diatoms As Water Quality Indicators In Spanish Shallow Lakes. Vie Milieu 54: 71-79. used in United Kingdom proved to be hardly sensitive to seasonal changes. The differences between its values calculated on the basis of diatom samples from the spring, summer and autumn proved to be insignificant [Bennnion et al. 2014].

The above examples indicate that the results of research on the impact of the seasonal variability of diatoms on bioindication are ambiguous. This issue needs to be re-tested specifically for the IOJ. The results of such research would make it possible to assess whether the collection of a single sample in a specific time interval is sufficient, or whether the time interval should be narrowed or samples should be collected several times in a year.

\section{CONCLUSIONS}

The comments made on the Polish method for the assessment of ecological status on the basis of phytobenthos are based on the results of research on lakes in different geographical regions, with a different trophic state, morphology and chemistry. Each of the factors that potentially differentiate phytobenthos should be tested on Polish lakes and its impact on phytobenthos in local conditions should be investigated. The important issue is not only whether the factors described here affect the very structure of phythobenthos but also whether a given impact can be seen in the results of assessments based on IOJ. The factors potentially affecting bioindication should be investigated. These include the diatom substrate and the spatial diversity of diatoms, both at the scale of the whole lake and at the vertical scale, as well as the temporal variability of a diatom assemblage. An exact analysis of these factors can indicate the potential directions of the development and improvement of the Polish phytobenthos lake assessment method.

\section{ACKNOWLEDGEMENTS}

Financial support for this study was provided by the Institute of Environmental Protection - National Research Institute. Inspection for Environmental Protection provided data obtained within the framework of state environmental monitoring. I would like to thank dr Hanna Soszka for valuable comments on the early version of the manuscript.

BRIX H. 1999. Genetic diversity, ecophysiology and growth dynamics of reed (Phragmites australis). Aquatic Botany 64: 179-184.

BROWN S-D., AUSTIN A.P. 1973. Diatom Succession and Interaction in Littoral Periphyton and Plankton. Hydrobiologia 43: 333-356.

CANTONATI M., LOWE R.L. 2014. Lake benthic algae: toward an understanding of their ecology. Freshwater Science 33: 475-486.

CASTENHOLZ R.W. 1960. Seasonal changes in the attached algae of freshwater and saline lakes in the Lower Grand Coulee, Washington. Limnology and Oceanography 5: 1-28.

CATTANEO A., GALANTI G., GENTINETTA S., ROMO S. 1998. Epiphytic algae and macroinvertebrates on submerged and 
floating-leaved macrophytes in an Italian lake. Freshwater Biology 39: 725-740.

CIECIERSKA H., KOLADA A. 2014. ESMI: a macrophyte index for assessing the ecological status of lakes. Environmental Monitoring and Assessment 186: 5501-5517.

CLEVERING O.A., LISSNER J. 1999. Taxonomy, chromosome numbers, clonal diversity and population dynamics of Phragmites australis. Aquatic Botany 64: 185-208.

DANILOV R.A., EKELUND N.G.A. 2000. The use of epiphyton and epilithon data as a base for calculating ecological indices in monitoring of eutrophication in lakes in central Sweden. The Science of the Total Environment 248: 63-70.

DENICOLAD.M., KELLYM. 2014. Role of periphyton in ecological assessment of lakes. Freshwater Science 33: 619-638.

Directive 2000/60/EC of the European Parliament and of the Council of 23 October 2000 establishing a framework for Community action in the field of water policy. Official Journal of the European Communities L 327/1 of 22.12.2000, 72 pp.

EMINSON D., MOSS B. 1980. The composition and ecology of periphyton communities in freshwaters. British Phycological Journal 15: 429-446.

EUROPEAN COMMISSION 2003. Common Implementation Strategy for the Water Framework Directive (2000/60/EC). Guidance Document No 7. Monitoring under the Water Framework Directive. Produced by Working Group 2.7 Monitoring, Luxembourg, Office for Official Publications of European Communities, 160 pp.

HILLBRICHT-ILKOWSKA A. 1997. Ekologiczne problemy gospodarowania jakością wód powierzchniowych oraz ich siedliskiem i przyrodą (The ecological problems of the management of quality of surface waters and their habitat and nature). In: Starkel L. (ed.) Użytkowanie a ochrona zasobów wód powierzchniowych w Polsce (The Use and Protection of Surface Water Resources in Poland - in Polish). Polish Academy of Sciences. Zeszyty Naukowe Komitetu "Człowiek i Środowisko" (Journal of the "Man and Environment" Committee) 17: 63-88.

HOAGLAND K.D., PETERSON C.G. 1990. Effects of light and wave disturbance on vertical zonation of attached microalgae in large reservoir. Journal of Phycology 26: 450-457.

HUTOROWICZ A., PASZTALENIEC A. 2014. Phytoplankton metric of ecological status assessment for Polish lakes and its performance along nutrient gradients. Polish Journal of Ecology 62: 525-542.

KAROSIENĖ J., KASPEROVIČIENÉ J. 2008. Seasonal succession of epiphyton algal communities on Phragmites australis (Cav.) Trin. ex Stend. in a mesoeutrophic lake. Ekologija 54: 32-39.

KAROSIENĖ J., PASKAUSKAS R. 2012. Spatial variability of epiphyton communities structure in a temperate estuarine lagoon. Estuarine, Coastal and Shelf Science 114: 100-104.

KAWECKA B., ELORANTA P.V. 1994. Zarys ekologii glonów wód słodkich i środowisk lądowych (An Outline of the Ecology of Algae of Freshwaters and Terrestrial Environments - in Polish). PWN Scientific Publishers, Warsaw 252 pp.

KELLY M. 2013. Data rich, information poor? Phytobenthos assessment and the Water Framework Directive. European Journal of Phycology 48: 437-450.
KELLY M., URBANIC G., ÁCS É., BENNION H., BERTRIN V., BURGESS A., DENYS L., GOTTSCHALK S., KAHLERT M., KARJALAINEN S.M., KENNEDY B., KOSI G., MARCHETTO A., MORIN S., PICIŃSKA-FAŁTYNOWICZ J., POIKANE S., ROSEBERY J., SCHOENFELDER I., SCHOENFELDER J., VARBIRO G. 2014. Comparing aspirations: intercalibration of ecological status concepts across European lakes for littoral diatoms. Hydrobiologia 734: 125-141.

KING L., BARKER P., JONES R.I. 2000. Epilithic algal communities and their relationship to environmental variables in lakes of the English Lake District. Freshwater Biology 45: 425-442.

KING L., CLARKE G., BENNION H., KELLY M., YALLOP M. 2006. Recommendations for sampling littoral diatoms in lakes for ecological status assessments. Journal of Applied Phycology 18: 15-25.

KITNER M., POULÍČKOVÁA. 2003. Littoral diatoms as indicators for the eutrophication of shallow lakes. Hydrobiologia 506509: 519-524.

KUDELSKA D., SOSZKA H., CYDZIK D. 1997. Ekosystemowe podejście do oceny jakości jezior w Polsce (An ecosystembased approach to the lake quality assessment in Poland - in Polish). Ochrona Środowiska i Zasobów Naturalnych 11: 85-92.

LAMBERT D., CATTANEO A., CARIGNAN R. 2008. Periphyton as an early indicator of perturbation in recreational lakes. Canadian Journal of Fisheries and Aquatic Science 65: 258-265.

LAUGASTE R., REUNANEN M. 2005. The composition and density of epiphyton on some macrophyte species in the partly meromictic Lake Verevi. Hydrobiologia 547: 137-150.

MÜLLER U. 1999. The vertical zonation of adpressed diatoms and other epiphytic algae on Phragmites australis. European Journal of Phycology 34: 487-496.

PEŁECHATY M. 2004. Can Reed Stands Be Good Indicators of Environmental Conditions of the Lake Littoral? A Synecological Investigation of Phragmites australis Dominated Phytocoenoses. Polish Journal of Environmental Studies 13: 177-183.

PICIŃSKA-FAŁTYNOWICZ J., BŁACHUTA J. 2010. Wytyczne metodyczne do przeprowadzenia oceny stanu ekologicznego jednolitych części wód rzek i jezior oraz potencjału ekologicznego sztucznych i silnie zmienionych jednolitych części wód płynących Polski na podstawie badań fitobentosu (Methodological guidelines for assessing the ecological status of bodies of rivers and lakes and the ecological potential of artificial and heavily modified bodies of running waters in Poland on the basis of phytobenthos surveys - in Polish). Chief Inspectorate for Environmental Protection, Wrocław 79 pp. http://www.gios. gov.pl/zalaczniki/artykuly/FB_2010.pdf [April 2015].

PICIŃSKA-FAŁTYNOWICZ J. 2011. Fitobentos (Phytobenthos). In: Soszka H. (ed.) Ocena stanu ekologicznego wód zlewni rzeki Wel (An assessment of the ecological status of waters in the Wel River catchment - in Polish). Inland Fisheries Institute, Olsztyn pp. 187-201.

POIKANE S. (ed.) 2014. Water Framework Directive Intercalibration Technical Report: Lake Phytobenthos ecological assessment methods. Luxembourg: Publications Office of the European Union, 978-92-79-35468-7, 140 pp. 
POULÍČKOVÁ A., DUCHOSLAV M., DOKULIL M. 2004. Littoral diatom assemblages as bioindicators of lake trophic status: A case study from perialpine lakes in Austria. European Journal of Phycology 39: 143-152.

ROSENBERGER E., HAMPTON S.E., FRADKIN S.C., KENNEDY B.P. 2008. Effects of shoreline development on the nearshore environment in large deep oligotrophic lakes. Freshwater Biology 53: 1673-1691.

SCHAUMBURG J., SCHRANZ C., STELZER D., HOFMANN G. 2007. Action Instructions for the ecological Evaluation of Lakes for Implementation of the EU Water Framework Directive: Macrophytes and Phytobenthos. Bavarian Water Management Agency. München $69 \mathrm{pp}$.

SCHNEIDERS.C., ŁAWNICZAKA.E.,PICIŃSKA-FAŁTYNOWICZJ., SZOSZKIEWICZ K. 2012. Do macrophytes, diatoms and nondiatom benthic algae give redundant information? Results from a case study in Poland. Limnologica 42: 204-211.

SHORTREED K.S., COSTELLA A.C., STOCKNER J.G. 1983. Periphyton biomass and species composition in 21 British Columbia lakes: seasonal abundance and response to wholelake nutrient additions. Canadian Journal of Botany. 62: 10221031.

SPITALE D., SCALFI A., LANGE-BERTALOT H., CANTONATI M. 2011. Using different epilithic-diatom assemblage metrics for an ecological characterization of the shores of Lake Garda. Journal of Limnology 70: 197-208.
SOSZKA H. 2002. Ocena i klasyfikacja wód powierzchniowych - ewolucja podejścia do zagadnienia [Assessment and classification of surface waters - an evolution of the approach to the issue - in Polish]. Ochrona Środowiska i Zasobów Naturalnych 23/24: 33-46.

STENGER-KOVÁCS C., BUCZKÓ K., HAJNAL E., PADISÁK J. 2007. Epiphytic, littoral diatoms as bioindicators of shallow lake trophic status: Trophic Diatom Index for Lakes (TDIL) developed in Hungary. Hydrobiologia 589:141-154.

THOMAS K.E., KLUKE A., HALL R.I., PATERSON A.M., WINTER J.G. 2011. Assessment of benthic algal biomonitoring protocols to evaluate effects of shoreline development on the nearshore zone of Precambrian Shield lakes in Ontario. Lake and Reservoir Management 27: 398-413.

VLAAMSE MILIEUMAATSCHAPPIJ 2009. Biological assessment of the natural, heavily modified and artificial surface water bodies in Flanders according to the European Water Framework Directive. Erembodegem, Belgium 76 pp. Manuscript.

ZĘBEK E., BONAR A., SZYMAŃSKA U. 2012. Periphytic diatom communities in the littoral zone of the urban lake Jeziorak Mały (Masurian Lake District, Poland). Ekológia (Bratislava) 31: 105-123. 